\title{
Építőipari kockázatok rétegei Analysis of construction risks of layer
}

\author{
I. CSERPES, J. SZABÓ \\ SZE Szerkezetépítési és Geotechnikai Tanszék; Multidiszciplináris Műszaki Tudományi Doktori Iskola, \\ cserpesi@sze.hu \\ Széchenyi István Egyetem
}

Absztrakt. A kockázat és a bizonytalanság nagyon régóta filozófiai, elvi viták tárgya. Mindkét fogalom azt a törekvést szolgálja, hogy jövőbeli események természetét és hatásait elemezzük, és elöre jelezzük. Különbségük viszont abban áll, hogy elemzésük más-más módon lehetséges. A bizonytalanság félelmet keltő, nehezen elemezhető, a kockázat pedig adatokkal jobban ellátott, módszertanilag könnyebben megközelíthetö, ezért elfogadhatóbb, kezelhetőbb jelenség. A cikk elméleti része azt állítja, hogy a kockázat és a bizonytalanság egy kockázati spektrumot jelöl ki. A következö állítás az, hogy a spektrum több egymásra rakódott rétegbőll áll: a kockázat és a bizonytalanság a két szélső pozíciót foglalja el.

Abstract. Risk and uncertainty are subjects of philosophic and theoretic discussions long time ago. Both concepts have the intention that nature and effects of future happenings have to be analyzed and forecasted. Difference is though that analysis is possible by different means. Uncertainty is frightening and hard to be analyzed. On the other hand, risk is better served by data, easier to find a methodology that makes it a more acceptable and manageable object. Theoretic part of the article states that risk and uncertainty entitle a risk spectrum. The next statement is that this spectrum has layers piled on one on the other, from which risk and uncertainty are the ones on the sides.

\section{Bevezető}

Kutatási munkánk és gyakorlati, módszertani kísérleteink, valamint praktikus eljárások kidolgozása során ismételten szembe kerültünk a kockázatokkal kapcsolatos adatszerzési, adatfeldolgozási, elemzési, értékelési és kockázatkezelési lehetőségek különbözőségeivel, valamint az eredmények megbízhatóságának változatosságával. Szükségét éreztük annak, hogy egy régi, de máig élő vitákat generáló megállapításból kiindulva osztályozzuk és összefüggő rendszerbe foglaljuk a kockázatokat.

A cikk alapvető célkitűzése ennek a rendszernek a felépítése. A rendszerezésnél figyelembe vettük az elméleti jellemzőket, de hasonló súllyal kezeltük a gyakorlati alkalmazás szempontjait is.

A rendszer építése az ebben a gondolatkörben sokat emlegetett kockázat versus bizonytalanság különbségtételből indult ki. A két fogalom által meghatározott jelenségeket egy különféle résztulajdonságokkal rendelkező, de azonos természetű, rétegekre bontható kockázati spektrum szélső rétegeiként határozzuk meg. A spektrum szélső rétegei között több réteget iktattunk be, ezek 
jellemzői fokozatosan változnak, ha az egyik szélső pozíció felől a másik felé haladunk. Elkészítettük a rendszer összefoglaló táblázatát, amely jól illusztrálja a gondolatmenetet.

A kutatás közvetlen indítéka az volt, hogy praktikus kérdések megválaszolása nehézséget okozott: milyen esetben mely adatforrás, elemzési módszertan alkalmas, hogyan változnak egy folyamat közben a körülmények, mikor lehet vagy kell másik elemzési módszert alkalmazni?

Mivel ezek a kérdések az építési projektek kockázatelemzése során merültek fel, cikkünk ezen a területen szolgál az elméleti megállapítások értelmezésével. Az értelmezést példával illusztráljuk, néhány módszerbeli újdonságot is bemutatva. A példa végigveszi az építési projekt fázisait, ezzel dinamikusan követve a kockázatelemzésnek a folyamat közben változó lehetőségeit és határait.

\section{A kockázati spektrum kijelölése}

A kockázatszámítás és a kockázatkezelés hosszú története számos matematikai és gazdasági felismerést hozott. A mai felfogások és elvek általánosan elfogadott kiindulópontja Knight műve [7]. A kockázat, a bizonytalanság és a profit című műben elég egyszerű, és ezért nagyon népszerű megállapítást tesz: „A bizonytalanságot (...) meg kell különböztetni a kockázat ismerős fogalmától (...) Úgy fog tűnni, hogy egy mérhető bizonytalanság vagy inkább »kockázat« (...) oly mértékben különbözik a nem mérhetőtől, hogy az a valóságban már egyáltalán nem is bizonytalanság.” A kortárs Keynes 1937-es összefoglaló művében, nagyon leegyszerűsítve gazdasági kérdések tekintetében elutasítja a kockázati elemzés valószínűségi alapjait, mert a bizonytalanság minden jövőbeli dolognál megmarad: „Meg kell különböztetnünk azt, amit biztosan tudunk, attól, ami csak valószínű.” „A rulettjáték nem tárgya a bizonytalanságnak...” Tegyük hozzá, hogy az általunk használt fogalomkör szerint a rulettjáték is kockázatokkal terhelt, hiszen abban is csak a hosszú távú, nagy mintaszámú tendencia biztos, egy eset kimenete viszont egyáltalán nem. Keynes kategorikusan kijelenti: „A társadalmi és gazdasági kérdésekkel kapcsolatban nincsenek tudományos alapjaink, amelyek révén bármi néven nevezendő kiszámítható valószínűséget kialakíthatnánk." [6]

A dolgozat fő célkitűzésének megfelelően olyan rendszert határozunk meg, amely a kockázatokkal kapcsolatos gyakorlati alkalmazásokhoz vezető utakat is vázolja. Az eddigi rövid ismertetés remélhetően elegendő alapot ad arra, hogy a kockázatot és a bizonytalanságot egy spektrum két szélének tekintsük, és arra is feljogosít, hogy a két véglet közötti teret rétegekre bontsuk. A kockázati spektrum egyik szélső értéke tehát a mérhető és kiszámítható kockázat, a másik pedig a nem ismert, nem számítható bizonytalanság, amiről csak annyit tudunk, hogy létezik, ismert, már előfordult. Ismét Knightra hivatkozva: a bizonytalanság meghatározhatatlan hatású, félelmet, szorongást keltő, a kockázat ellenben megfelelő adatok alapján elemezhető dolog. Elfogadható az az álláspont is, hogy a bizonytalanságnak is van meghatározható része, csak elemzésére az eszközeink nem alkalmasak, vagy olyan jelenségekről van szó, amelyekben az esetlegesség domináns, és a (csak elméletileg) meghatározható rész elenyésző. 
A kockázat viszont jórészt számszerűen is elemezhető részből áll. De itt is tudomásul kell venni, hogy akármennyire „pontosan kiszámítható” a kockázat, „biztos dolgok nincsenek” vagyis valamilyen mértékű kiszámíthatatlanság mindig van.

Ha kockázattal állunk szemben, akkor mivel az elemzés jól megismerhetővé teszi, felkészülhetünk, intézkedhetünk, sőt gyakran arról is dönthetünk, vállaljuk-e. A bizonytalanság felé haladva egyre nehezebb az elemző dolga, mert az elemzés alapjai is egyre gyengébbek.

Ha az eddigi okfejtés elfogadható, akkor a kockázati spektrum két szélső rétegét már -legalább is nagy vonalakban - jellemeztük is. A továbbiakban több közbenső réteget jelölünk ki, ajánlást téve azok definiálására és jellemzésére.

Röviden foglalkozni kell még azzal a gyakran hangoztatott felvetéssel, hogy a kockázat soha sem lehet pusztán objektív jellemző, bármennyire is pontosan meghatározható, mert a kockázatot szubjektív tényezők is befolyásolják. Ez természetesen így van, az egyéni tényezők - mint a percepció, a kockázatra való érzékenység, az érzékelés, egyéni megítélés - azonban minden személynél mások. Ebben a dolgozatban a szubjektív - mindig a befogadás, a kockázatérzékelés oldalán jelentkező elemeket figyelmen kívül hagyjuk. Ez semmiképpen sem jelenti azt, hogy a szubjektív kockázatértékelést jelentéktelennek vagy elhanyagolhatónak tartanánk. Knight óta ugyanis úgy tartjuk, hogy a profit forrása a kockázatvállalás, ami eleve szubjektív megfontolásokon alapszik [7]

A kizárás oka itt az, hogy gyakorlati feladatok megoldás esetében a kockázatelemző oldal, tehát nem a kockázatviselő szemléletét kell figyelembe venni. A kockázatelemzésnél tehát mindig objektív szemléletet feltételezünk, még akkor is, ha a szakértő vagy a szakértői csoportok becslésre, netán találgatásra kényszerülnek, véleményüket átlagolják, esetleg még szavaznak is.

Tehát: az elemzést a kockázat és a bizonytalanság közötti spektrumban kell megoldanunk. Ami ezen a spektrumon kívül van (ezt a bizonytalanság oldalán talán veszedelemnek nevezhetnénk), nem elemezhető, mert semmilyen ismeretünk nincs róla, nem tudunk semmit a lehetséges következményekről. A veszedelmek váratlanul csapnak le, következményei is ismeretlenek, sokszor tehetetlenséget, bénultságot előidézve jelentkeznek. A veszedelem a megismeréssel megszűnik veszedelem lenni, mert ekkor már a bizonytalanság kategóriájába kerül.

A bizonytalanság és a kockázat közötti spektrum másik szélén kívül pedig a teljesen kiszámítható, száz százalékban előre jelezhető következmények lennének, nevezzük ezeket biztos eseménynek, ezek létét azonban már korábban kizártuk. A méréseknek itt nem kockázatelemzés, tehát a jövőbeli kockázatokra vonatkozó számítás elvégzése, hanem a statisztikai adatrögzítés szempontjából van jelentőségük, ami a következő elemzés pontosságát javíthatja. A „majdnem biztos” jövőbeli események közé tartoznak a gyakran ismételt gyártási műveletek: a jövő ekkor akár néhány percen belül bekövetkezik.

Kijelöltünk tehát egy spektrumot, amelyen belül az elemzés szempontjából folyamatos átmenetet feltételezünk, és most ezt a spektrumot módszertani és adatellátási szempontokra figyelemmel a kockázattól a bizonytalanságig több kockázati rétegre osztjuk fel. Az elemzés eredményét, bármelyik rétegben is vagyunk, mindig kockázatnak nevezzük, mert az elemzés eredménye, bármilyen hiányos 
ismereteken alapul is, bármilyen nagyvonalú becsléssel készül, bármilyen módszertannal állapították is meg, mindig azonos jellegű. A kockázat fő mérőszáma a vizsgált jellemző (selejt mennyisége, tervezett költségtől, időtől való eltérés, kibocsátás stb.) várható értéke, és emellett fontos az előre jelezhető alsó és felső érték, valamint az így kijelölt határok közötti megoszlás.

\section{A kockázati spektrum rétegződése}

Ha a kockázati spektrumban a leginkább meghatározható kockázattól indulunk el, akkor az adatforrásokra és az elemzési módszerek jellegére vonatkozóan a következő rétegeket jelölhetjük ki:

- közvetlenül mérhető, számítható kockázatok

- közvetve számítható kockázatok

- szakvéleménybe foglalható kockázatok

- becsléssel meghatározható kockázatok

- nem-valószínűségi kockázatok

A közvetlenül mérhető, számítható kockázatok esetében lehet leginkább arra számítani, hogy a közeljövő nagyon hasonlít a közelmúltra, egy holnapi selejtadat hasonlít a maihoz és a tegnapihoz. Minden ismétlődő folyamat, rutinművelet elemezhető ilyen módon. Ha egy műveletet hosszabb időn át megfigyelünk, mérjük az eredményt, akkor számíthatunk arra, hogy az a jövőben is hasonló lesz. Ez tehát az elő rétegbe tartozó kockázat, amelyet a kockázatviselő saját maga megmérhet, kiszámíthat, kisebb-nagyobb körben elfogadott normákkal kiszámolhat, esetleg saját normákat állíthat fel, és az alapján elemezhet.

A közvetve számítható rétegbe sorolt kockázatoknál a saját mérések és megfigyelések mellett külső adatforrásokra szorulunk, vagy ilyeneket is igénybe veszünk.

Szakértőhöz fordulhatunk bármilyen esetben, de a szakértői véleményt kifejezetten igénylő helyzeteket soroljuk a következő rétegbe. Szakértőnek azt nevezzük, aki tapasztalatokkal, az adott területen fölényes tudással rendelkezik, ismeri a kérdés szakirodalmát, adatbázisokba, statisztikai adatokba tud betekinteni, és emellett képes helyszíni megfigyeléseket és vizsgálatokat is elvégezni.

A becslések tartományában, ez a következő kockázati réteg, két árnyalatot különböztetünk meg. Az előző bekezdésben leírt szakvélemény tapasztalatokon, adatelemzéseken és számításokon alapszik. A szakértő viszont gyakran kap olyan jellegű kérdéseket, amelyekre határozott válasz nem adható, mert annak kimunkálásához valamilyen feltétel nem adott. Ilyenkor arra kényszerül, hogy válaszát becslésekre alapozza. A szakértői becslés önállóan vagy szakvélemény részeként nagyon gyakran előforduló elem.

Elérkeztünk a spektrum széléhez, a nem-valószínűségi kockázati rétegbe, a véleményeken és az elhatározáson alapuló elemzésekhez. Nincs megbízható adat, nincs stabil viszonyítási pont, csak távoli analógiák, hasonló helyzetek, megérzések. Itt igen-nem, akarom-nem akarom, jóváhagyják-elvetik és hasonló végletes lehetőségek és ilyen események együttes bekövetkezését, valamint elenyészően kis 
valószínűségű, de nagyon erős hatásokkal fenyegető kockázatokat kell elemezni. Foltos, homályos képet látunk. A szokásos kockázati megfontolások nem vezetnek eredményre.

Összefoglaló táblázatban foglaljuk rendszerbe, amit az egymásra rakódó rétegekről írtunk.

\begin{tabular}{|c|c|c|c|c|}
\hline Kockázati réteg & $\begin{array}{l}\text { Kockázati } \\
\text { jellemző }\end{array}$ & Tipikus adatforrás & $\begin{array}{l}\text { Elemzési } \\
\text { módszertan }\end{array}$ & Matematikai eszközök \\
\hline $\begin{array}{l}\text { Biztos } \\
\text { események }\end{array}$ & \multicolumn{4}{|c|}{ A kockázati spektrumon kívüli események } \\
\hline $\begin{array}{l}\text { Közvetlenül } \\
\text { mérhető, } \\
\text { számítható } \\
\text { kockázatok }\end{array}$ & $\begin{array}{l}\text { Mérhető, } \\
\text { megfigyelheto,, } \\
\text { számítható, } \\
\text { általában } \\
\text { nagyszámú } \\
\text { minta }\end{array}$ & $\begin{array}{l}\text { Saját előírások, } \\
\text { mérések, } \\
\text { számítások, } \\
\text { statisztika }\end{array}$ & $\begin{array}{l}\text { Részletes } \\
\text { tervek, } \\
\text { statisztikai } \\
\text { módszerekkel } \\
\text { kiértékelt } \\
\text { megfigyelések }\end{array}$ & $\begin{array}{l}\text { Eloszlások vizsgálata } \\
\text { kontrollkártyákkal és } \\
\text { más hasonló } \\
\text { eszközökkel, jellemző a } \\
\text { normális eloszlás, egyes } \\
\text { területeken } \\
\text { aszimmetrikus, de } \\
\text { markáns jellemzőkkel } \\
\text { rendelkező eloszlások } \\
\text { (szórás, variancia, } \\
\text { középértékek) }\end{array}$ \\
\hline $\begin{array}{l}\text { Közvetve } \\
\text { számítható } \\
\text { kockázatok }\end{array}$ & $\begin{array}{l}\text { Részben saját } \\
\text { tevékenységen } \\
\text { mérhető, de } \\
\text { máshol } \\
\text { statisztikai } \\
\text { szempontból } \\
\text { jól feldolgozott }\end{array}$ & $\begin{array}{l}\text { Saját és idegen } \\
\text { mérések, } \\
\text { statisztikai adatok, } \\
\text { iparágra jellemző } \\
\text { adatgyűjtemények }\end{array}$ & $\begin{array}{l}\text { Saját és idegen } \\
\text { statisztika } \\
\text { egybevetése }\end{array}$ & $\begin{array}{l}\text { Saját és idegen adatok } \\
\text { párhuzamos } \\
\text { felhasználása, markáns } \\
\text { jellemzőkkel rendelkező } \\
\text { eloszlások, Bayes tétele }\end{array}$ \\
\hline $\begin{array}{l}\text { Szakvéleménybe } \\
\text { foglalható } \\
\text { kockázatok }\end{array}$ & $\begin{array}{l}\text { Szakértő } \\
\text { segítségét } \\
\text { igénylő, de jól } \\
\text { meghatározott }\end{array}$ & $\begin{array}{l}\text { Szakmai } \\
\text { segédletek, } \\
\text { kimutatások, } \\
\text { statisztikák, } \\
\text { szakértői tudás }\end{array}$ & $\begin{array}{l}\text { Szakértői } \\
\text { számítások, } \\
\text { elemzések, } \\
\text { szakvéleménybe } \\
\text { foglalva }\end{array}$ & $\begin{array}{l}\text { Statisztikai, iparági } \\
\text { adatelemzés és } \\
\text { értékelés, számítások } \\
\text { vagy eloszlások, fuzzy- } \\
\text { analízis, Markov-láncok }\end{array}$ \\
\hline $\begin{array}{l}\text { Becsléssel } \\
\text { meghatározható } \\
\text { kockázatok }\end{array}$ & $\begin{array}{l}\text { Ritkább, de } \\
\text { jelentős hatású } \\
\text { jelenségek, } \\
\text { szórt, } \\
\text { egymásnak } \\
\text { esetleg } \\
\text { ellentmondó } \\
\text { jellemzők }\end{array}$ & $\begin{array}{l}\text { Szakmai } \\
\text { segédletek, } \\
\text { kimutatások, } \\
\text { statisztikák, } \\
\text { Szakértői tudás és } \\
\text { invenció, } \\
\text { tapasztalat }\end{array}$ & $\begin{array}{l}\text { Szakértői } \\
\text { számítások és } \\
\text { megfontolások, } \\
\text { szakértői } \\
\text { becslésként } \\
\text { feldolgozva }\end{array}$ & $\begin{array}{l}\text { Statisztikai, iparági } \\
\text { adatok felhasználásával } \\
\text { végzett becslés, kevéssé } \\
\text { határozott } \\
\text { eloszlásfüggvények vagy } \\
\text { tapasztalati adatok } \\
\text { rendezése, fuzzy- } \\
\text { analízis }\end{array}$ \\
\hline $\begin{array}{l}\text { Nem- } \\
\text { valószínúségi } \\
\text { kockázatok }\end{array}$ & $\begin{array}{l}\text { Ritkán } \\
\text { jelentkező, } \\
\text { nagyon nagy } \\
\text { hatású } \\
\text { események }\end{array}$ & $\begin{array}{l}\text { Jellemzően } \\
\text { adathiány, } \\
\text { tapasztalat hiánya, } \\
\text { statisztikailag } \\
\text { elemezhetetlen } \\
\text { információk }\end{array}$ & $\begin{array}{l}\text { Feltételezések, } \\
\text { változó } \\
\text { paraméterekkel } \\
\text { végzett } \\
\text { becslések }\end{array}$ & $\begin{array}{l}\text { Boole-algebra, FMA } \\
\text { elemzés, fuzzy-analízis, } \\
\text { szcenárióelemzés }\end{array}$ \\
\hline Veszedelmek & \multicolumn{4}{|c|}{ A kockázati spektrumon kívüli események } \\
\hline
\end{tabular}

\section{4. Építési projektek gyakorlati kockázatelemzése}

\subsection{Az építési projekt sajátosságai}


A kockázati felfogások és elvek általános elvi kérdései után áttérhetünk gyakorlati jellegű témánkra, az építési projektek kockázatelemzésére. Az építési projektek adatainak beszerzésével, meghatározásának lehetőségeivel, megbízhatóságával, illetve használatukkal kapcsolatos kérdéseket úgy tekintjük át, hogy azzal az elméleti részben taglalt elvek értelmezésére és gyakorlati alkalmazására adjunk példát.

Ez a fejezet a korábban egy népes kutatói csoport által készített munkára támaszkodik, amely munka részleteit a kutatási projekt dokumentumai tartalmazzák, de itt elegendőnek ítéljük a tanulmánykötet anyagára való hivatkozást: [8]

A bevezető részben a kockázatok több rétegre bontott spektrumát mutattuk be. Az építési projekt fázisaiban minden réteg azonosítható, a projektekben ugyanis az adatok megbízhatósága széles határok között mozog. Ez nem véletlen, mivel az építési projekt sokszereplős, különféle tevékenységek bonyolult együttese. Elég, ha arra utalunk, hogy milyen nagy különbség van a politikai döntések és az építéskivitelezési munka körülményei, céljai, szabályrendszere, kiszámíthatósága és ütemezhetősége között.

A hivatkozott kutatási munka során meghatároztuk általánosságban és egy mintapéldán keresztül az építési projektek fázisait. Feltételeztük, hogy a teljes folyamatra lehet egy hálótervet készíteni, majd a hálóterv egyszerűsítésével, csak a kritikus utat figyelembe véve szekvenciális, egymás után következő fázisokat megállapítani. A hálótervet CPM/PERT rendszertechnikával rajzoltuk meg, természetesen annak tudatában, hogy a két módszer több szempontból is eltér egymástól. Az egyszerűsítés célja az volt tehát, hogy az építési projekt egészét azonos grafikai elemekkel ábrázoljuk, és hasonló módszerrel elemezzük. A klasszikus PERT-hálót igénylő mezőkben is határozott tevékenységeket jelölünk ki, illetve a CPM-hálónál a számított-kalkulált jellemzőket is valószínűségi változóként kezeljük. Eljárásunk tehát hibridnek tekinthető.

A kétféle gondolkodásmód és szemlélet különbségét áthidalja a technikai hasonlóság. A projektek lefutásának, tervezésének leírására kombinált, kevert technikát, CPM/PERT hálóterveket használunk, ismerve, tudomásul véve, de átlépve a két módszer tankönyvi kettéválasztását. [5] Az építési projektek egymást követő tevékenységeinek egymástól nagyon eltérő körülményei azt kívánják, hogy úgy a CPMháló tevékenységre-folyamatokra és meghatározott tevékenység-időtartamokra, mint a PERT-hálók eseményekre (kezdési és befejezési időpontokra), valamint a pontos tevékenység-leírásokra, bizonytalan időtartamokra irányuló szemléletét is figyelembe vegyük.

\subsection{Az építési tevékenységek kockázatelemzésének jellemző adatforrásai}

Az építési projektek elemzése során a már hivatkozott munkában két jellemzőre számítottunk kockázatokat. Az időtartamot és a költségeket ítéltük az egész projektre kiható hatásúnak, úgy gondoltuk, hogy ezek alakulása jól reprezentálja az egész projektet. További kutatási terveinkben szerepel az építés harmadik nagyon fontos jellemzője, a minőség bevonása a kockázatelemzésikezelési vizsgálati körbe. 
Az elemzéshez szükséges adatforrásokat tekintve a különféle szakmai területeken sajátos normarendszerek alakultak ki. Ez a helyzet az építőiparban is. Az építőipari normák egy-egy építési szerkezetre vonatkoznak. Szerkezeti egység például egy köbméter egylyukú kémény falazása kisméretű téglából, egy négyzetméter négy centiméter vastag aszfaltbeton készítése, egy folyóméter meghatározott átmérőjű és minőségű csővezeték fektetése. Az építési normák jellemzően munkások, gépek tevékenységét és anyagszükségletét együttesen mérik és szabályozzák. A szerkezetre vonatkozó normasorozat (akkord) elemei természetesen összhangban vannak egymással. A normaakkordnak mindig van egy meghatározó eleme: domináns lehet a gépi munka, ekkor az emberi munkát kell ehhez igazítani, a másik gyakori esetben fordított helyzet áll elő, az emberi munkához kell a gépeket rendelni. Az első esetet gép-ember, a másikat ember-gép kapcsolatnak nevezik. Ritkább, de előfordul, hogy az anyagellátás üteme a meghatározó.

Az építőipari normákat normakönyvekbe foglalták, ezek évtizedek óta közkézen forognak, állandóan gondozzák, fejlesztik. Ha új szerkezetek, technológiák, anyagok, gépek jelennek meg, akkor a normákat bővítik, javítják, módosítják. Ma természetesen már elektronikus kiadás és a normákkal való számításokat segítő szoftverek is forgalomban vannak. Meg kell itt említenünk, hogy az általános használatú normagyűjteményeket elsősorban költségkalkulációra való használatra fejlesztik.

Normának tekinthetünk minden mérhető, szabályokba foglalt módon meghatározott jellemzőt. Ismétlődő tevékenységre, műveletre lehet normákat képezni. Ha normáról beszélünk, akkor követelménynek tekinthető értékekről van szó, amelyek sokszor fontos alapot képeznek gazdasági vagy más szempontból, a norma tehát mérő és szabályozó eszköz.

A normák megállapítása többféle módon lehetséges. A normák egy része számítható. Egyszerűen kijelenthetjük, hogy egy hatszemélyes vacsorához hat székre van szükség. Egyszerű geometriai számítással megállapíthatjuk, hogy egy négyzetméter padlóhoz mennyi padlólap szükséges. Megfelelő szakértelemmel ennél sokkal bonyolultabb esetekben is tudunk számolni. A gépek megadott teljesítménye alapján sokszor kiszámíthatjuk az elérhető kibocsátás nagyságát.

A normatívák a külön-külön normázott tevékenységek összevont normái. A produktumhoz tartozó tevékenységek normái itt már nem alkalmasak, hanem az eredmény, a produktum alakulása figyelhető meg. Például, a sok művelettel elóálítható - például gyártási folyamatok, belső mozgatások, ellenőrzések, csomagolás, szállítás előkészítése - termékek esetében megfigyelhető, mérhető a kibocsátás nagysága, mondjuk csomagban kifejezve naponként, és ez tekinthető normatívának, ami még talán a normák valamilyen aggregálásával is számítható lenne. Akkor viszont, ha az üzem többféle terméket állít elő, és például a napi kibocsátást pénzben kívánjuk kifejezni, akkor már egy kevésbé pontos, naponta nagyobb ingadozást mutató normatívát használhatunk. Minél többféle tevékenység összevont eredményét kívánjuk egy értékkel, normatívával kifejezni, annál jobban vagyunk kénytelenek becslésekhez, statisztikai adatokhoz folyamodni. Például: építsünk egy nagy kórházat! Régóta nem épült ilyen, mit tegyünk? Húsz évre indexálva számítsuk át a költségeket? A mostanában végzett hasonló munkák bővítések, felújítások voltak, az új építések pedig ennél a nagyságrendnél jóval szerényebbek. Számítsuk a jellemzőket ágyszám szerint, négyzetméterre, légköbméterre, orvosi létszámra, az ellátott területen élő népesség szerint? 
A normatívák is rendszerbe foglalhatók, ismertek ilyen példák, nyilvános kiadásukra leginkább külföldi példák vannak. Magyarországon az jellemző, hogy beruházók, tanácsadók és a piac más szereplői saját, nem nyilvános gyűjtésükből dolgoznak. Egy rendszeresen frissített, a nyilvánosság számára hozzáférhető normatívagyűjtemény nagyon hiányzik.

Ahogy egyre kevesebbet tudunk a projekt részleteiről, annál nehezebb dolgunk van. Az a helyzet, hogy ahogy egyre bonyolultabb, egyedi vagy kevésbé jól meghatározható építésre kívánunk árakat adni, egyre kevesebb és egyre kevésbé pontos adatokra számíthatunk. A megbízható normatíváktól elindulva haladunk tehát abba az irányba, amerre egyre több becslésre, tapasztalati adatra, sőt megérzésre szorulunk. Néhány fokozatot felállítva beszélhetünk tehát az összevont normákból és gyakorlati esetek tapasztalati adataiból összegyúrt normatíváról, szakértői véleménybe foglalt normatívákról, szakértői becslésről, tapasztalati becslésről, illetve elsődleges, előzetes becslésről.

Hiába tartjuk a fokozatok többségét nagyon közelítőnek, esetleg komolytalan találgatásnak, a projekt minden fázisában, mindennek árat kell adni, minden döntést a költségek alapján hoznak meg. A költségek nélkül, legyenek azok bármennyire is hozzávetőlegesek, egyszerűen semmiféle tervet nem lehet készíteni. Közismert és tanulságos irodalmi példa a háborúból: a katonai szolgálatot teljesítő tudósoktól több napra időjárás-előrejelzést kértek a légierő parancsnokai. A kérést nem lehet teljesíteni, válaszolták. És a viszontválasz: „... a tábornok tudatában van annak, hogy a meteorológiai előrejelzések semmit sem érnek. Mégis szüksége van rájuk a soron lévő feladatok tervezéséhez." [1]

\subsection{Kockázati rétegek}

Az 1. táblázat felosztásának megfelelően az építési projektek körülményeit és sajátosságait tükröző példát, értelmezést készítettünk, a 2. táblázat szerint. Ezt az összeállítást, az 1. táblázathoz hasonlóan új megközelítésnek tekintjük.

\begin{tabular}{|c|c|c|c|c|}
\hline $\begin{array}{l}\text { Általános kockázati } \\
\text { rétegek, építési fázisok }\end{array}$ & $\begin{array}{l}\text { Építőipari kockázati } \\
\text { tényezők }\end{array}$ & $\begin{array}{l}\text { Tipikus } \\
\text { adatforrás }\end{array}$ & $\begin{array}{l}\text { Elemzési } \\
\text { módszertan }\end{array}$ & $\begin{array}{l}\text { Matematikai } \\
\text { eszközök }\end{array}$ \\
\hline Biztos események & \multicolumn{4}{|c|}{ A kockázati spektrumon kívüli események } \\
\hline $\begin{array}{l}\text { Közvetlenül mérhető, } \\
\text { számítható kockázatok, } \\
\text { ismert technológiájú, } \\
\text { rész-letesen } \\
\text { megtervezett építési } \\
\text { kivitelezés }\end{array}$ & $\begin{array}{l}\text { Időjárás, emberi } \\
\text { hiba, anyaghiba stb. }\end{array}$ & $\begin{array}{l}\text { Saját vállalati } \\
\text { normák, iparági } \\
\text { általános } \\
\text { normák }\end{array}$ & $\begin{array}{l}\text { Normától } \\
\text { való eltérések } \\
\text { gyakor-lati } \\
\text { megfigyelése, } \\
\text { statisztikai } \\
\text { feldolgozása }\end{array}$ & $\begin{array}{l}\text { Tevékenységek } \\
\text { nél béta- } \\
\text { eloszlás, } \\
\text { tevékenységsor } \\
\text { ozatnál } \\
\text { központi } \\
\text { határeloszlás }\end{array}$ \\
\hline $\begin{array}{l}\text { Közvetve számítható } \\
\text { kockázatok, külön-leges } \\
\text { technológiával készített } \\
\text { szerkezetek, műszaki } \\
\text { tervezési munkák, } \\
\text { kiviteli terv hiányában } \\
\text { végzett kivitelezés }\end{array}$ & $\begin{array}{l}\text { Tervezési, szerve- } \\
\text { zési bizonytalanság, } \\
\text { nem eléggé részletes } \\
\text { tervek, technológia } \\
\text { kiforratlansága, } \\
\text { képzettségi hiányok }\end{array}$ & $\begin{array}{l}\text { Saját és részben } \\
\text { idegen, normák } \\
\text { összevonásával } \\
\text { készült } \\
\text { normatívák }\end{array}$ & $\begin{array}{l}\text { A } \\
\text { normatíváktó } \\
\text { l való } \\
\text { eltérések } \\
\text { megfigyelése, } \\
\text { statisztikai } \\
\text { feldolgozása }\end{array}$ & $\begin{array}{l}\text { Tevékenységek } \\
\text { nél béta- } \\
\text { eloszlás, } \\
\text { tevékenységsor } \\
\text { ozatnál } \\
\text { központi } \\
\text { határel-oszlás, } \\
\text { növekvő } \\
\text { szórással }\end{array}$ \\
\hline $\begin{array}{l}\text { Szakvéleménybe fog- } \\
\text { lalható kockázatok, nem } \\
\text { vagy csak felületesen }\end{array}$ & $\begin{array}{l}\text { Nem precíz feladat- } \\
\text { meghatározás, } \\
\text { részben ismeretlen }\end{array}$ & $\begin{array}{l}\text { Általános hasz- } \\
\text { nálatú normatí- } \\
\text { vák, hasonló }\end{array}$ & $\begin{array}{l}\text { Szakértői } \\
\text { mérlegelés, } \\
\text { tapasztalati }\end{array}$ & $\begin{array}{l}\text { Tevékenységek } \\
\text { nél béta- } \\
\text { eloszlás, }\end{array}$ \\
\hline
\end{tabular}




\begin{tabular}{|c|c|c|c|c|}
\hline $\begin{array}{l}\text { ismert feladatok, } \\
\text { nagyvona-lúan } \\
\text { meghatározott keretek } \\
\text { alapján törté-nő tervezés, } \\
\text { vázlatos tervek alapján } \\
\text { történő építés }\end{array}$ & $\begin{array}{l}\text { feladatok, rossz } \\
\text { építési körülmények }\end{array}$ & $\begin{array}{l}\text { építmények ada- } \\
\text { tainak felhaszná- } \\
\text { lása, szakértői } \\
\text { tudás és gyakor- } \\
\text { lati tapasztalati } \\
\text { adatok }\end{array}$ & $\begin{array}{l}\text { adatok } \\
\text { alapján } \\
\text { számítások, } \\
\text { eloszlások } \\
\text { viszonylag } \\
\text { precíz } \\
\text { meghatározás } \\
\text { a }\end{array}$ & $\begin{array}{l}\text { tevékenységsor } \\
\text { ozatnál } \\
\text { központi } \\
\text { határeloszlás, } \\
\text { növekvő } \\
\text { szórással }\end{array}$ \\
\hline $\begin{array}{l}\text { Becsléssel meghatá- } \\
\text { rozható kockázatok, } \\
\text { nagyon nagyvonalú-an } \\
\text { meghatározott feladatok, } \\
\text { bizony-talan kimenetelű } \\
\text { eljárások és fejlesz-tési } \\
\text { folyamatok, a projekt- } \\
\text { szervezet } \\
\text { kialakulatlansága }\end{array}$ & $\begin{array}{l}\text { Műszaki, gazdasági } \\
\text { és finanszírozási } \\
\text { döntések bizony- } \\
\text { talanságai, hatósági } \\
\text { eljárások, partnerek } \\
\text { viselkedésének } \\
\text { kiszámíthatatlanság } \\
\text { a }\end{array}$ & $\begin{array}{l}\text { Megvalósult vagy } \\
\text { tervezett } \\
\text { létesítmények } \\
\text { adatai, megfelelő } \\
\text { normatívák és } \\
\text { minták } \\
\text { használata, } \\
\text { szakmai } \\
\text { gyakorlat és } \\
\text { intuíció }\end{array}$ & $\begin{array}{l}\text { Szakértői } \\
\text { gyakorlati } \\
\text { tapasztalatok } \\
\text { alapján } \\
\text { végzett } \\
\text { számítások, } \\
\text { becslések } \\
\text { arányosítássa } \\
\text { l, saját } \\
\text { tapasztalatok } \\
\text { és mások } \\
\text { megkérdezés } \\
\text { ével }\end{array}$ & $\begin{array}{l}\text { Bizonytalan } \\
\text { centrumú, } \\
\text { szórás nélküli, } \\
\text { eloszlások } \\
\text { alkalmazása, } \\
\text { fuzzy-analízis }\end{array}$ \\
\hline $\begin{array}{l}\text { Nem-valószínűségi } \\
\text { kockázatok }\end{array}$ & $\begin{array}{l}\text { Nagyon vázlatosan } \\
\text { meghatározott célok } \\
\text { és feladatok, } \\
\text { kiforratlan } \\
\text { szervezeti keretek }\end{array}$ & $\begin{array}{l}\text { Távoli minták, } \\
\text { legalább néhány } \\
\text { paraméter meg- } \\
\text { határozása (pél- } \\
\text { dául terjedelem, } \\
\text { költség, } \\
\text { megvaló-sítás } \\
\text { időkerete) }\end{array}$ & $\begin{array}{l}\text { Intuíció, } \\
\text { gyakorlati } \\
\text { tapasztalatok, } \\
\text { a lehetséges } \\
\text { hatások } \\
\text { mérlegelése }\end{array}$ & $\begin{array}{l}\text { Események } \\
\text { össze- } \\
\text { függéseinek } \\
\text { becslése, } \\
\text { valószínűségek } \\
\text { köze-lítő } \\
\text { meghatározása } \\
\text {, mennyiségek } \\
\text { becs-lése, FMA- } \\
\text { analízis, fuzzy- } \\
\text { elemzés }\end{array}$ \\
\hline Veszedelmek & \multicolumn{4}{|c|}{ A kockázati spektrumon kívüli események } \\
\hline
\end{tabular}

\section{A kutatás további fő irányai}

A kutatás során számos elméleti és a gyakorlati kérdés maradt megválaszolatlanul. A lényegesebbeket a szövegben megneveztük, szándékunk szerint könyvjelzőkkel jelezve a további kutatások irányát. Különösen fontosnak tartjuk az egyes kockázati rétegekhez illeszkedő módszertani javaslatok részletesebb bemutatását példákon keresztül, a kockázatérzékelés és a szubjektív elemek módszertani megalapozását, valamint az új területeken való értelmezést az itt bemutatott minta alapján.

\section{Hivatkozás}

[1] Bernstein, P.L. (1996): Szembeszállni az istenekkel. Panem Kiadó-John Wiley\&Sons, Budapest

[2] Cserpes I. (2016): Az építési projekt fázisai és a kockázati tényezők összefüggései. GRADUS 3. 
[3] Cserpes I., Szabó J. (2016): Építőipari kockázatok vizsgálata. International Journal of Engineering and Management Sciences, Műszaki és Menedzsmenttudományi Közlemények 1.

[4] Farkas Sz., Szabó J. (2005): A vállalati kockázatkezelés kézikönyve. Dialóg-Campus, Budapest-Pécs

[5] Kaufmann, A. (1972): Pontok, élek, ívek, gráfok. Műszaki Könyvkiadó, Budapest

[6] Keynes, J.M. (1937): The General Theory of Employment. Quarterly Journal of Economics, February

[7] Knight, F.H. (1921): Risk, Uncertainly and Profit. Hart, Schaffner\&Marx-Houghton Mifflin Co., Boston, MA

[8] Kovács N. (szerk.) (2014): Építőkockák. Tanulmánykötet. Universitas-Győr Nonprofit Kft.

[9] Kovács N., Koppány K. (2014): Kockázatelméleti és módszertani építőkockák. In: Kovács N. (szerk.): Építőkockák. Tanulmánykötet. Universitas-Győr Nonprofit Kft.

[10] Koppány K. (2014): Építőipari szakértői vélemények összegyűjtése és aggregálása. In: Kovács N. (szerk.): Építőkockák. Tanulmánykötet. Universitas-Győr Nonprofit Kft. 